\title{
Surface Properties and Adsorption Capacities of Rice Bran-Activated Carbon
}

\author{
Dewa Ngakan Ketut Putra Negara ${ }^{1,2^{*}}$, Tjokorda Gde Tirta Nindhia ${ }^{1}$, \\ Wayan Nata Septiadi ${ }^{1}$ \\ ${ }^{1}$ Mechanical Engineering Department, Udayana University, \\ J1. Raya Kampus Unud, Bukit Jimbaran, South Kuta, Badung Bali, 80361, Indonesia \\ ${ }^{2}$ Master Program of Mechanical Engineering, Udayana University, Jalan P.B. Sudirman, Denpasar Bali, \\ 80232, Indonesia \\ *Corresponding author:devputranegara@unud.ac.id
}

\section{ABSTRACT}

The growing need for activated carbon requires alternative raw materials to replace non-renewable raw materials whose existence is decreasing. Biomass is a very promising precursor, one of which is from rice bran. This research concerns the development of activated carbon derived from rice bran. Carbonization was carried out at $600{ }^{\circ} \mathrm{C}$ and physically activated with nitrogen flow rates of $150 \mathrm{~mL} / \mathrm{min}$ for 40,80 , and 120 minutes. The activated carbons produced (AC-D40, AC-D80, and AC-D120) were characterized to determine the surface properties, surface morphology, and adsorption capacity for nitrogen and blue methylene adsorptions. The results showed that activated carbon that activated for 80 minutes (AC-D80) had the best characteristics. With a pore surface area of $109.389 \mathrm{~m}^{2} / \mathrm{g}$, a pore volume of $0.083 \mathrm{~cm}^{3} / \mathrm{g}$, and pores that mostly distributed in the micropore area, this activated carbon has the highest adsorption for nitrogen $\left(53.874 \mathrm{~cm}^{3} / \mathrm{g}\right)$ and methylene blue $(87.560 \mathrm{mg} / \mathrm{g})$ adsorptions compared to activated carbon with activation times of 40 minutes (AC-D40) and 120 minutes (AC-D120).

Copyright $\odot$ 2020. Journal of Mechanical Engineering Science and Technology.

All rights reserved.

Keywords: Activated carbon, activation, adsorption, characteristic, rice bran, surface

\section{Introduction}

Activated carbon is an adsorbent that has unique characteristics. It has a high pore volume and surface area that causes activated carbon to have high adsorption. Because of its high adsorption capacity, activated carbon widely applied in various fields of life such as for the purification of water from industrial waste pollutants [1] [2], removal of methylene blue [3]-[5], a cathode battery material in electrochemical devices [6], $\mathrm{CO}_{2}$ adsorption [7] [8], biogas purification [9] [10], and supercapacitor [11].

To be applied optimally, the properties or characteristics of activated carbon and the type of adsorbate to be adsorbed must be well known. For instance, for gas storage and purification, the surface characteristics of activated carbon such as pore-volume, surface area, and distribution of pore size play an important role. In the gas storage process, an adsorption process occurs, which is the accumulation of gas molecules on the surface of the activated carbon due to the Van der Walls forces. The pore volume, surface area, and pore distribution of activated carbon determine the number of gas molecules that can be adsorbed. The behavior of porous media such as movement and fluid flow are largely influenced by these characteristics. The pore size distribution of activated carbon is the relative pore 
volume associated with different pore sizes [12], and in gas storage and separation application strongly associated with adsorption capacity [13].

The high use of activated carbon demands high availability of activated carbon as well. Unfortunately, the raw material for activated carbon generally comes from coal or petroleum residue, whose availability is decreasing. Some researchers have started to develop activated carbon using raw materials from biomass such as palm-shell [14], rice straw [15], agricultural solid wastes [16], chips from spruce and birch [17], and bamboo [18][19]. But it is still very minim literature associated with activated carbon made from rice bran. Rice bran is a waste from rice milling with a proportion of $10 \%$ of the weight of rice harvested [20]. The chemical composition and physical element content of rice bran strongly determined by rice varieties and environmental factors.

The characteristics and quality of activated carbon depend on the chemical and physical properties of the precursor [21], the activator, the temperature, and the method of activation [22]. The process of making activated carbon consists of dehydration of raw materials, carbonization, and activation processes. Dehydration is done to reduce the moisture content of raw materials. Carbonization is carried out by heating the raw material at a temperature of $400-850^{\circ} \mathrm{C}$ [23] in order to form an initial porosity. Activation is a process to form new porosity, widen the porosity that has been formed during the carbonization process and can be done without involving agents (physical activation) and by involving agents (chemical activation). The purpose of this study was to determine the characteristics and adsorption ability of activated carbon derived from rice bran that is physically activated with different activation times.

\section{Material and Methods}

\section{A. Production of Activated Carbons}

The raw material used as activated carbon is rice bran obtained from the home industry of the rice mill in Banjar Pengaji, Payangan, Gianyar Bali Indonesia, as shown in Figure 1 (a). Thermo Gravimetric Analyzer (TGA) test results showed that rice bran contained $15.04 \%$ moisture, $62.05 \%$ volatile, $13.21 \%$ ash, and $9.7 \%$ fixed carbon. Rice bran is dried under the sunlight for seven days for 5 hours from 10.00 AM to 03.00 PM and meshed with 60 mesh. The meshed powder was dried in an electric furnace at $105^{\circ} \mathrm{C}$ for 2 hours. A 20 gram of dried powder rice bran was loaded into a stainless cylindrical reactor, and the reactor was then entered into an electric furnace for furthermore heated to a temperature of $600^{\circ} \mathrm{C}$. The heating was held at that temperature for 40 minutes, at the same time, an activation process was carried out by flowing nitrogen with a flow rate of $150 \mathrm{~mL} / \mathrm{min}$. The activated carbon cooled in the electric furnace for 12 hours. The same steps were carried out for activation times of 80 and 120 minutes. The produced activated carbons were then coded as AC-D40, AC-D80, and AC-D120 for the activation period of 40, 80, and 120 minutes, respectively. The sample of activated carbon produced is shown in Figure 1(b).

\section{B. Characterization of Activated Carbons}

Characterization carried out included SEM, adsorption isotherm, and methylene blue tests. SEM test equipment (JSM-651OLA) was used to observe the activated carbon surface morphology. Adsorption isotherm test equipment (The Micromeritics ${ }^{\circledR}$ TriStar II Plus) was applied to determine the surface structure of the activated carbon, including pore surface area $\left(\mathrm{S}_{\mathrm{BET}}\right)$, pore-volume, and adsorption of nitrogen. Methylene blue test was undertaken to determine the adsorption of activated carbon against methylene blue using an Ultra Violet- 
Visible (UV-Vis) spectroscopy. Determination of the adsorption of methylene blue by measuring the maximum wavelength of the $5 \mathrm{mg} / \mathrm{L}$ methylene blue solution in the range 664 $\mathrm{nm}$.

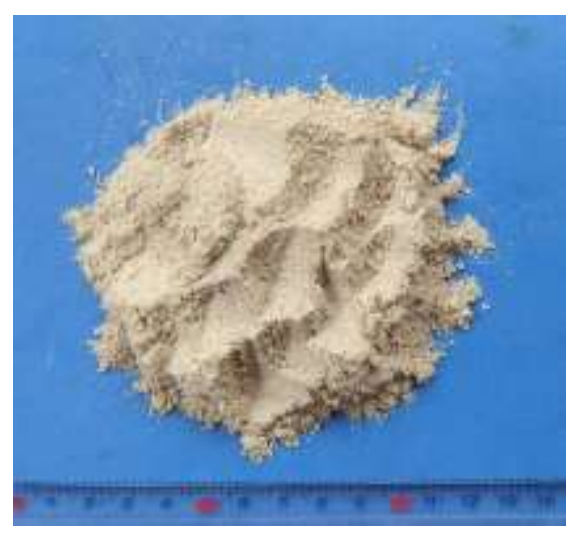

(a) Rice bran

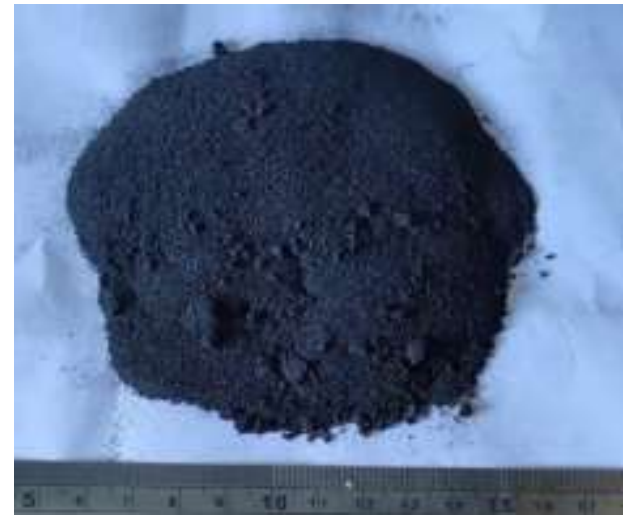

(b) Activated carbon

Fig.1. Precursor and sample of activated carbon produced

\section{Results and Discussions}

\section{A. Adsorption Isotherm of Activated Carbons}

The adsorption isotherm of activated carbon, as shown in Figure 2, is the relationship of the amount of nitrogen absorbed by activated carbon at different relative pressure levels. The three activated carbons produced have almost the same pattern, only differing in the rate of nitrogen adsorption. The activated carbon AC-DP40 has the lowest adsorption rate, whereas the relative pressure increases the amount of nitrogen adsorbed is relatively constant until the relative pressure of 0.9 . Then it increases significantly and reaches a peak at a relative pressure of 1 . The low absorption of activated carbon AC-D40 is due to its short activation time resulting in less opportunity for the formation of new pores and widening of the pores formed during the carbonization process. As a result, this activated carbon has a low surface area and pore volume as shown in Figure. 4 and 5.

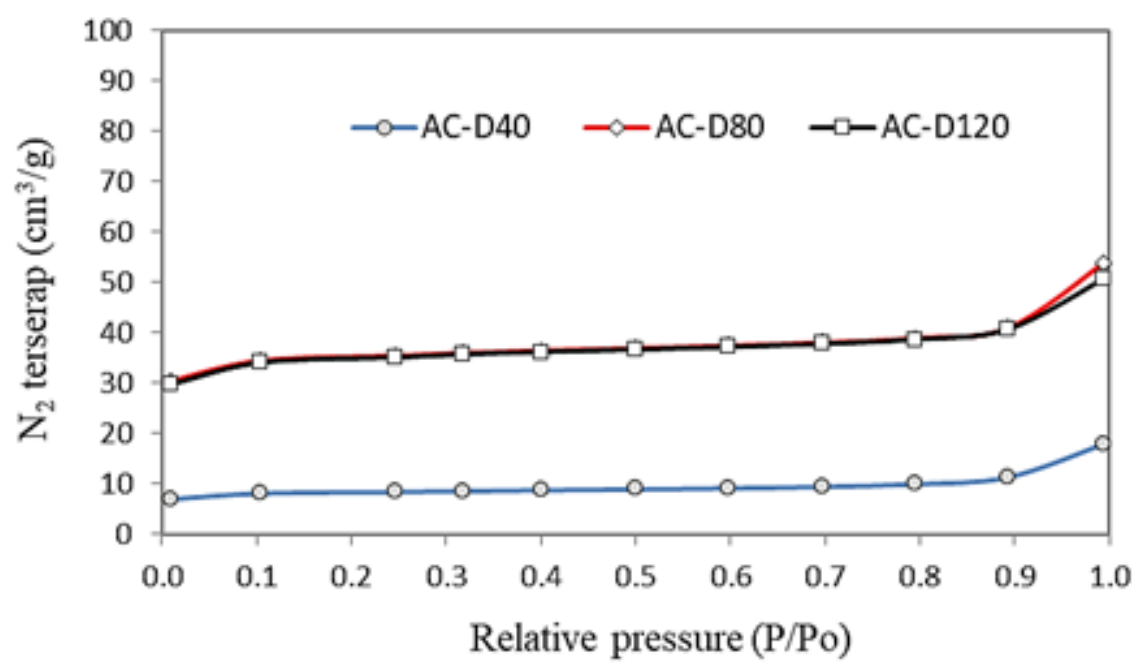

Fig. 2. Adsorption isotherm of activated carbons 
Whereas AC-D80 and AC-D120, nitrogen adsorption began to increase until the relative pressure of 0.1 , then remain constant until the relative pressure was 0.9. From a relative pressure of 0.9 , it increases dramatically and reaches a peak at relative pressure 1 . Both activated carbons have a Type II of adsorption isotherm classification related to IUPAC1985 [24]. In this type, there is a single and double layers adsorption mechanism that is characterized by a convex shape at a relative pressure $\left(P / P_{O}\right)$ less than 0.2 followed by a linear form over a long-range. The point of transition from convex to linear is the condition for the completion of single layer adsorption and when entering the linear portion indicates the start of double-layer adsorption [24]. Activated carbon AC-D80 and AC-D120 have higher adsorption at all relative pressure levels compared to AC-D40. At the end of the adsorption process, AC-D80 has a higher nitrogen adsorption capacity than AC-D120.

\section{B. Pore Size Distribution of Activated Carbons}

The pore size distribution is a graph that shows the relationship between the amount of nitrogen absorbed per gram of activated carbon at different pore sizes. As shown in Figure. 3 , the three activated carbons have almost the same pore distribution pattern. Most of them are distributed in the micropore area (less than $2 \mathrm{~nm}$ ) in the $0.4 \mathrm{~nm}$ to $1.75 \mathrm{~nm}$ range, but with different adsorption rates. AC-D80 has a pore size distribution with a peak adsorption rate of $0.0089 \mathrm{~cm}^{3} / \mathrm{g}$ at a pore diameter of $0.652 \mathrm{~nm}$, followed by AC-D120 and AC-D40 with the highest adsorption rates of $0.00837 \mathrm{~cm}^{3} / \mathrm{g}$ and $0.00227 \mathrm{~cm}^{3} / \mathrm{g}$, at pore diameter of $0.652 \mathrm{~nm}$ and $0.591 \mathrm{~nm}$, respectively. Even though they are in almost the same distribution range (micropore area), activated carbon AC-D40 has the lowest adsorption capacity. The 40-minutes activation duration of activated carbon AC-D40 provided less opportunity for the formation of new pores or widening of existing pores during the activation process. As a result, the number of pores formed is also less compared to activated carbons AC-D80 and AC-D120.

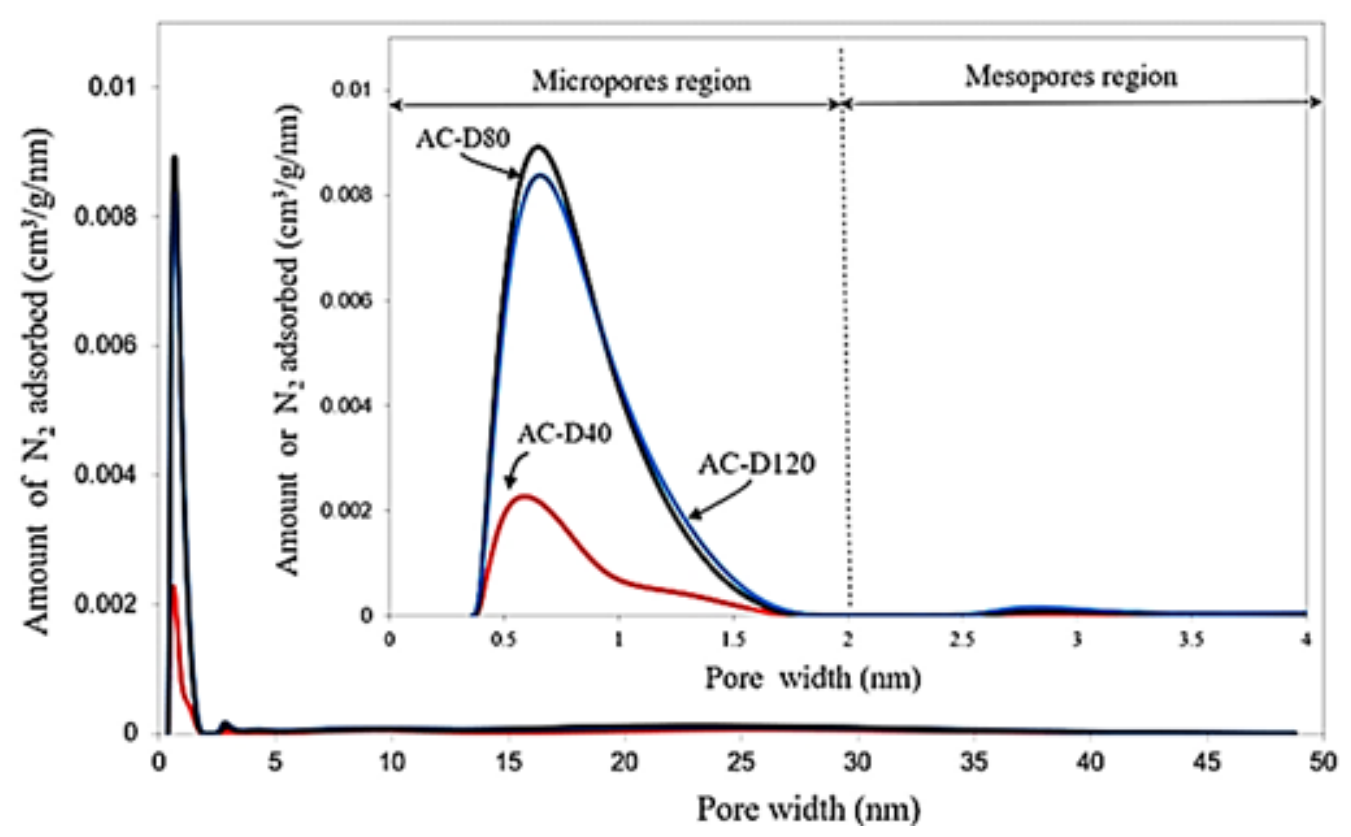

Fig. 3. Pore size distribution of samples 


\section{Surface Pore Structure of Activated Carbons}

The surface pore structure of the activated carbons, as shown in Figure. 4 and 5, show that produced activated carbons have a pore surface varying from $26.613-109.389 \mathrm{~m}^{2} / \mathrm{g}$, and pore volume from $0.028-0.083 \mathrm{~cm}^{3} / \mathrm{g}$. Activated carbon AC-D80 has the highest surface area and pore volume followed by AC-DP120 and AC-DP40. In this case (Figure. 4 and 5), the pore surface area of activated carbon is proportional to the pore volume, where the higher the pore surface area higher the pore volume of activated carbon. The existence of pores in the surface of activated carbons is shown in the SEM image of the surface morphology of activated carbon in Figure. 6, where there is a difference between the morphology of precursors and activated carbon. The formation of pores occurs when the precursor was heated in the carbonization process [25] [26] and then continued in the activation process [21].

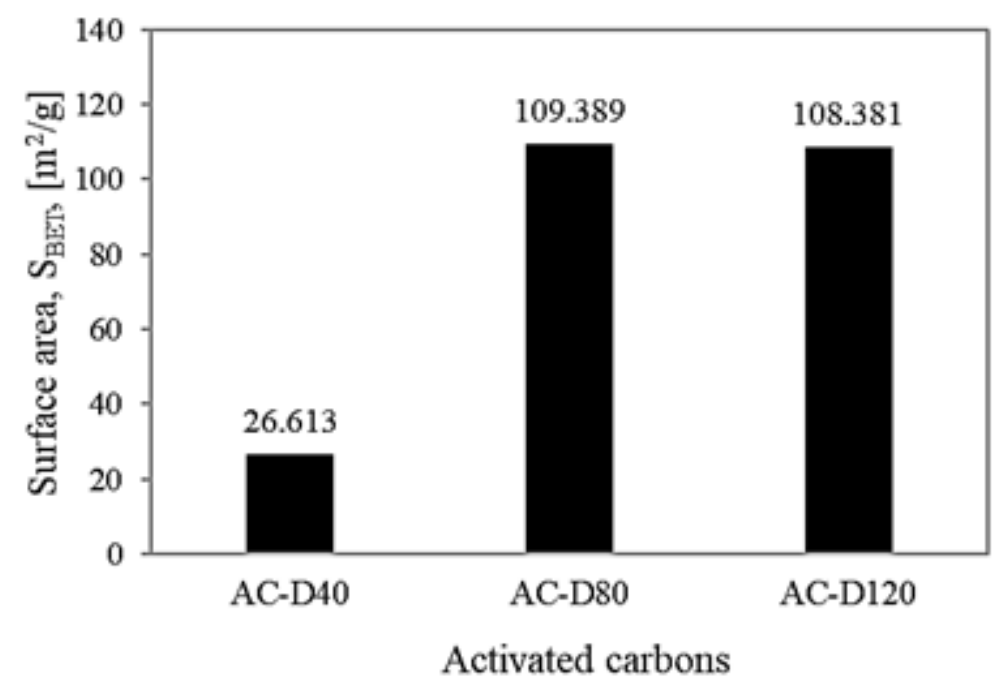

Fig. 4. Surface area $\left(\mathrm{S}_{\mathrm{BET}}\right)$ of activated carbons

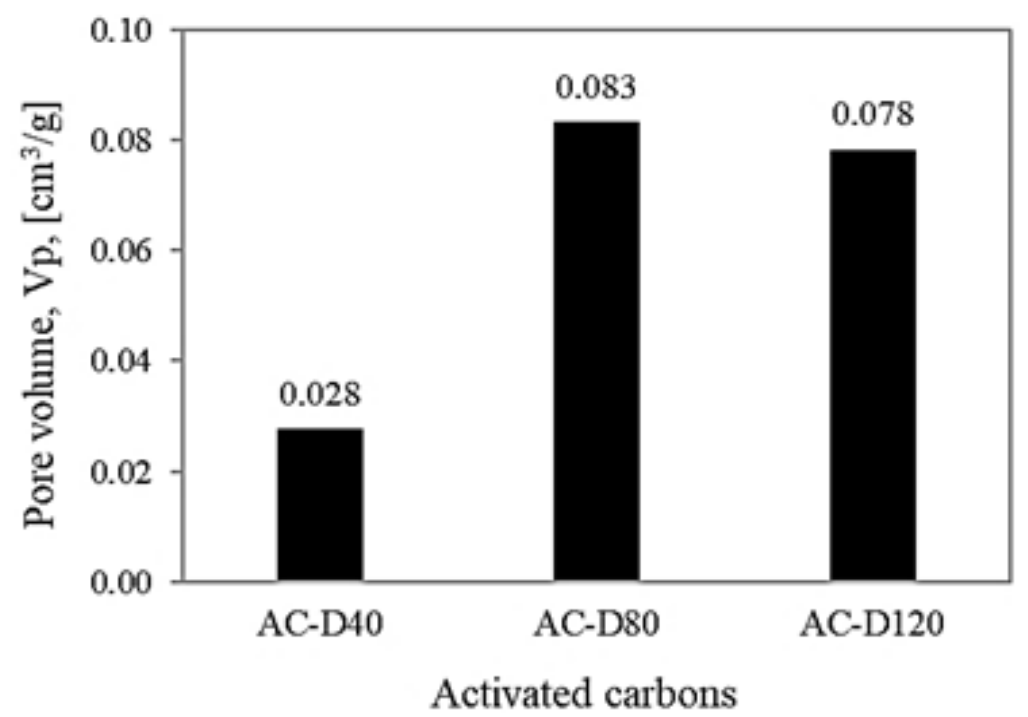

Fig. 5. Pore volumes of activated carbons 


\section{Adsorption of Nitrogen and Methylene Blue Through Activated Carbons}

The adsorption capacity of activated carbons for nitrogen and methylene blue is presented in Table 1. Activated carbon AC-D80 has the highest adsorption capacity of nitrogen and methylene blue. In this case, there is a linear relationship between the pore surface area, pore-volume, and the adsorption capacity of nitrogen and methylene blue. The higher the surface area and pore volume of activated carbon, the higher the adsorption capacity. Activated carbon AC-D80 that has the highest pore area $\left(109.389 \mathrm{~m}^{2} / \mathrm{g}\right)$ and the highest pore volume $\left(0.083 \mathrm{~cm}^{3} / \mathrm{g}\right)$, also has the highest adsorption of nitrogen $(53.874$ $\mathrm{cm}^{3} / \mathrm{g}$ ) and methylene blue $87.56(\mathrm{mg} / \mathrm{g})$. The comparison of methylene blue adsorption of the activated carbons produced in this study and other adsorbents is shown in Table 1.

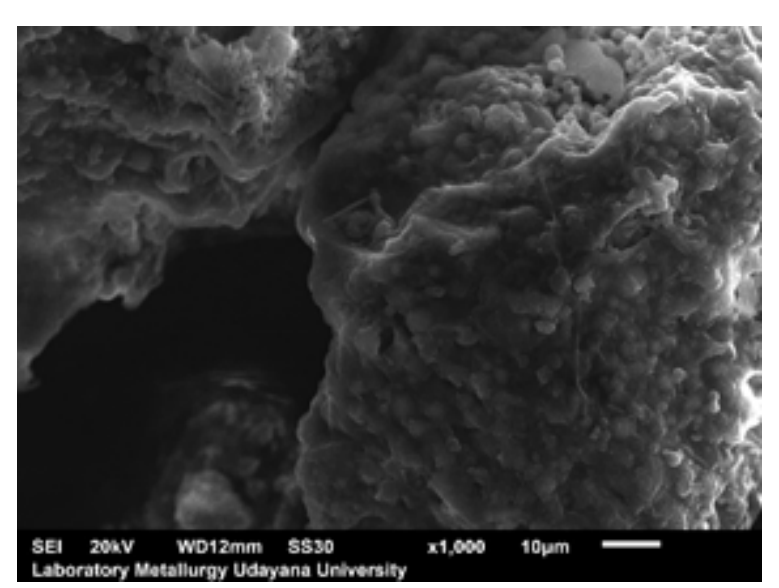

Rice bran

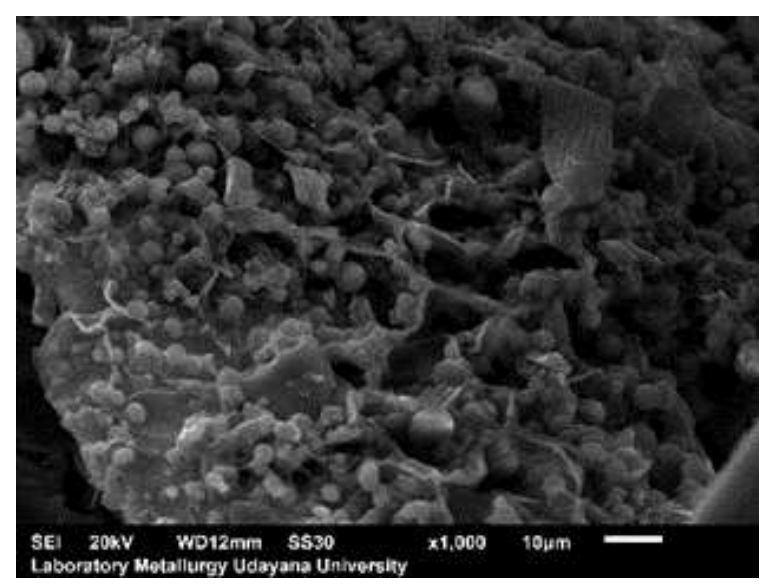

AC-D80

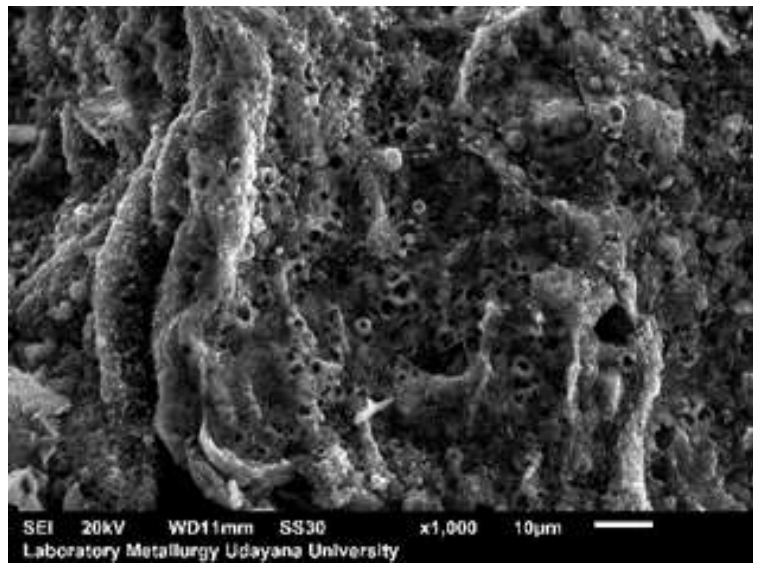

AC-D40

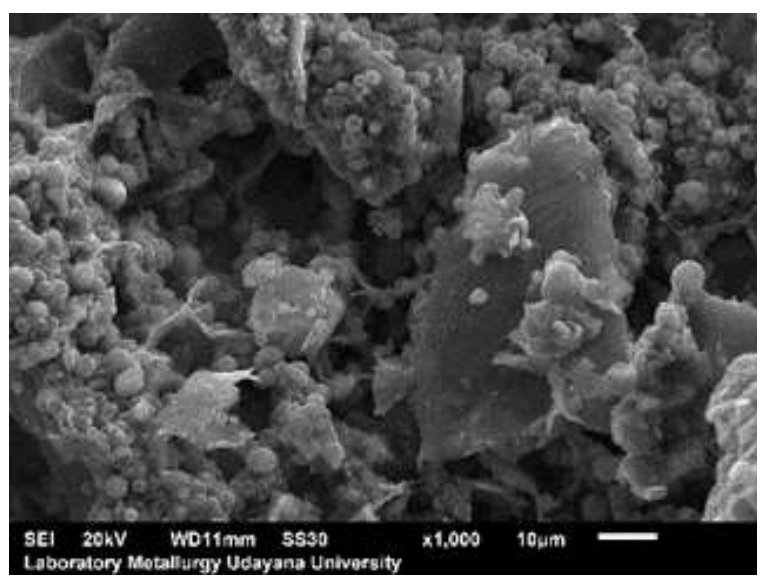

AC-D120

Fig. 6. Surface morphology of activated carbon 


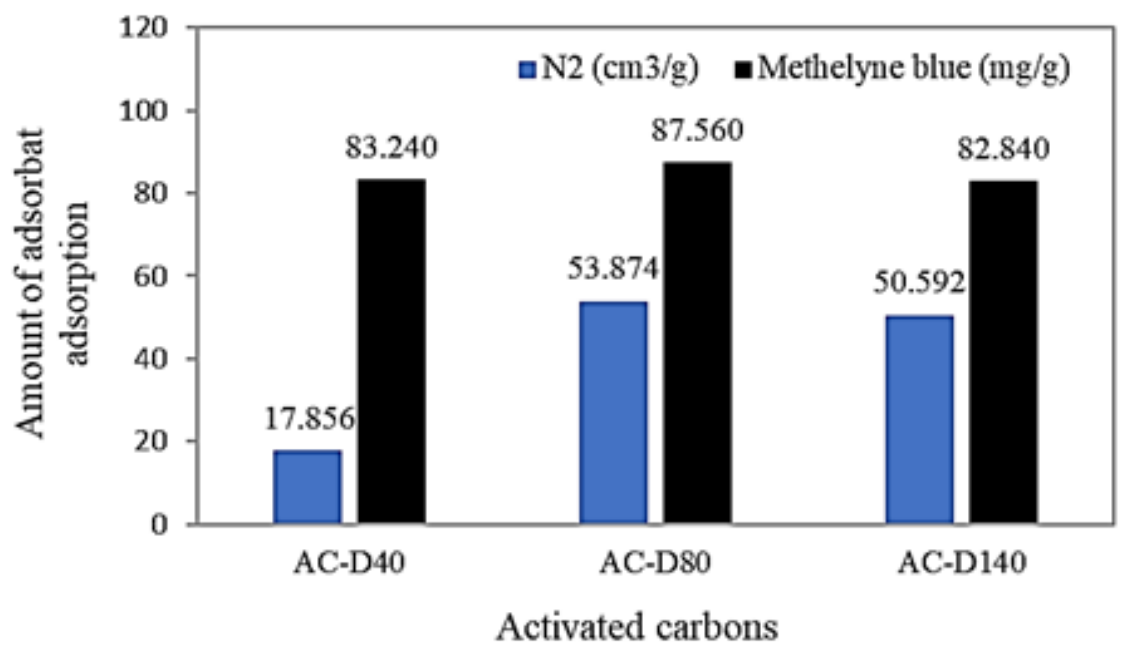

Fig. 7. Adsorption capacity of activated carbon

Table 1. Methylene blue adsorption capacity of some adsorbents

\begin{tabular}{|c|c|c|}
\hline Adsorbens/Activated carbons & $\begin{array}{l}\text { Methylene blue adsorbed } \\
\qquad[\mathrm{mg} / \mathrm{g}]\end{array}$ & References \\
\hline Rice bran & $82.84-87.56$ & This study \\
\hline $\begin{array}{l}\text { Modified activated carbon by } \\
\text { surfactants }\end{array}$ & $64.4-195.7$ & [27] \\
\hline Periwinkle & $89.8-431.1$ & {$[28]$} \\
\hline Shells activated carbon & & \\
\hline $\begin{array}{l}\text { Parthenium hysterophorus activated } \\
\text { carbon with } \mathrm{H}_{2} \mathrm{SO}_{4} \text { treated }\end{array}$ & 39.7 & [29] \\
\hline $\begin{array}{l}\text { Bagasse activated carbon with } \mathrm{H}_{2} \mathrm{SO}_{4} \\
\text { treatment }\end{array}$ & $49.8-56.5$ & {$[30]$} \\
\hline $\begin{array}{l}\text { Ficus carica activated carbon with } \\
\mathrm{H}_{2} \mathrm{SO}_{4} \text { treatment }\end{array}$ & 47.6 & {$[31]$} \\
\hline $\begin{array}{l}\text { Delonix regia pods activated carbon } \\
\text { with } \mathrm{H}_{2} \mathrm{SO}_{4} \text { treatment }\end{array}$ & 23.3 & {$[32]$} \\
\hline Coconut leaves activate carbon & $127-149$ & {$[33]$} \\
\hline
\end{tabular}

\section{Conclusions}

The rice bran precursor has been manufactured to become activated carbon with promising characteristics. Activated carbon that produced with an activation duration of 80 minutes (AC-D80) has the most optimal properties and adsorption capacity. With increasing surface area and pore volume, the adsorption capacity of activated carbon to nitrogen and methylene blue also increases. Activated carbon AC-D80 has the greatest surface area, porevolume, and ability for adsorption of nitrogen and methylene blue. With its characteristics, activated carbon AC-D80 has the potential to be used for the purification of biogas from $\mathrm{CO}_{2}$ and $\mathrm{H}_{2} \mathrm{~S}$ impurities or for adsorption of motor vehicle exhaust emissions. 


\section{Acknowledgment}

The deep thanks to conveyed to the Institute of Research and Community Services of Udayana University (LPPM Unud) through the Faculty of Engineering Udayana University, which has funded the flagship research of this study program (PUPS).

\section{Reference}

[1] Cheung, W.H., Lau, S.S.Y., Leung, S.Y., Ip, A.W.M., and McKay, G., "Characteristics of Chemical Modified Activated Carbons from Bamboo Scaffolding", Chinese Journal of Chemical Engineering, vol. 20 (3), pp. 515-23, 2012.

[2] Esteves, I. A.A.C., Marta, S.S.L., Pedro, M.C. N., and José, P.B. M, "Adsorption of Natural Gas and Biogas Components on Activated Carbon", Separation and Purification Technology, vol. 62 (2), pp. 281-96, 2008.

[3] Zohre, S., Ataallah, S.G., and Mehdi, A.W., "Experimental Study of Methylene Blue Adsorption from Aqueous Solutions onto Carbon Nano Tubes", International Journal of Water Resources and Environmental Engineering, vol. 2 (2), pp. 016-028, March 2010.

[4] Al Othman, Zeid, A., Mohamed, A.H., Rahmat, A., Ayman, A.G., and Mohamed, S., El-din H, "Valorization of Two Waste Streams into Activated Carbon and Studying Its Adsorption Kinetics, Equilibrium Isotherms and Thermodynamics for Methylene Blue Removal", Arabian Journal of Chemistry, vol. 7 (6), pp. 1148-1158, 2014.

[5] Yu, K., Xiaoping, Z., and Shaoqi, Z., "Adsorption of Methylene Blue in Water onto Activated Carbon by Surfactant Modification", Water, vol. 12 (587), pp. 1-19, February 2020.

[6] Gu, X., Wang, Y., Lai, C., Qiu, J., Li, S., Huo, Y.L., Martens, W., Mahmood, N., and Zhang, S, "Microporous Bamboo Biochar for Litium - Sulfur Battery", Nano Research, pp. 1-14, 2014.

[7] Peredo-Mancilla, D., Ghouma, I., Hort, C., Camelia, M. G., Jeguirim, M., and Bessieres, D., " $\mathrm{CO}_{2}$ and $\mathrm{CH}_{4}$ Adsorption Behavior of Biomass-Based Activated Carbons", Energies, vol. 11 (3136), pp. 1-13, 2018.

[8] L. Jiang, A. Gonzalez-Diaz, J. Ling-Chin, A.P. Roskilly, A.J. Smallbone, "Combustion $\mathrm{CO}_{2}$ Capture from A Natural Gas Combined Cycle Power Plant Using Activated Carbon Adsorption”, Applied Energy, vol. 245, pp. 1-15, 2019.

[9] Maile, O.I., Muzenda, E., Tesfagiorgis, H., "Chemical Adsorption of Carbon Dioxide in Biogas Purification”, Procedia Manufacturing, vol. 7, pp. 639-646, 2017.

[10] Sutanto, J.W.S., Dijkstra, J.A.Z. Pieterse, J. Boon, Hauwert, P., Brilman, D.W.F., “ $\mathrm{CO}_{2}$ Removal From Biogas with Supported Amine Sorbents: First Technical Evaluation Based on Experimental Data", Separation and Purification Technology, vol. 184, pp. 12-25, 2017.

[11] Huang, T., Qiu, Z., Wu, D. and Hu, Z, "Bamboo-Based Activated Carbon @ $\mathrm{MMO}_{2}$ Nanocomposites for Flexible High-Performance Supercapacitor Electrode Materials", Int. J. Electrochem. Sci, vol. 10, pp. 6312-6323, 2015. 
[12] Kuila, U., "Measurement and Interpretation of Porosity and Pore Size Distribution in Mudrocks: The Hole Story of Shales." A thesis, Doctor of Philosophy, Petroleum Engineering, The Colorado School of Mines, 2013.

[13] Sych, N. V., Trofymenko, S.I., Poddubnaya, O.I., Tsyba, M.M., Sapsay, V.I., Klymchuk, D.O., and Puziy, A.M., "Porous Structure and Surface Chemistry of Phosphoric Acid Activated Carbon from Corncob," Applied Surface Science, vol. 261, pp. 75-82, 2012.

[14] Khalil, S. H, "Effects on Surface Area, Intake Capacity and Regeneration of Impregnated Palm-Shell Activated Carbon with Monoethanolamide and 2-Amino-2Methyl-1-Propanol Equipped for $\mathrm{CO}_{2}$ Adsorption", Journal of Earth Science \& Climatic Change, vol. 9 (7), pp. 2-10, 2018.

[15] Hassan, A.H., and Sami, M.A.A., "Removal of Nitrate and Nitrite Anions from Wastewater Using Activated Carbon Derived from Rice Straw", Journal of Environmental \& Analytical Toxicology, vol. 6 (1), pp. 1-6, 2016.

[16] El-Demerdash, F.M., Abdullah, A.M., and Ibrahim, D.A, "Removal of Trihalo Methanes Using Activated Carbon Prepared from Agricultural Solid Wastes," Hydrology current research, vol. 6 (1), pp. 1-6, 2015.

[17] Bergna, D., Varila, T., Henrik , R.U.L., "Comparison of the Properties of Activated Carbons Produced in One-Stage and Two-Stage Processes", Journal of Carbon Research, vol. 4 (41), pp. 1-10, 2018.

[18] Negara, D.N.K.P., Tirta Nindhia, T.G., Surata, I.W., Hidajat, F., and Sucipta, M.,“ Nanopore Structures, Surface Morphology, and Adsorption Capacity of Tabah Bamboo-Activated Carbons", Surfaces and Interfaces, vol. 16, pp. 22-28, 2019.

[19] Negara, D.N.K.P., Tirta Nindhia, T.G., Lusiana, Astika, I.M., and Kusuma Kencanawati, C.I.P., "Development and Characterization of Activated Carbons Derived from Lignocellulosic Material", Materials Science Forum, vol. 988, pp. 8086, 2020.

[20] Akbarillah, T., Hidayat dan Khoiriyah, T., "Rice brand quality of several rice varieties In North Bengkulu", Jurnal Sain Peternakan Indonesia, vol. 2(1), pp. 36-41, 2007. (In Indonesia)

[21] Patil, B.S. and Kulkarni, K.S, "Development of High Surface Area Activated Carbon from Waste Material", International Journal of Advanced Engineering and Studies (IJAERS), vol. 1, pp. 109-113, 2012.

[22] Lempang, M., "Pembuatan dan Kegunaan Arang Aktif", Info Teknis EBONI, vol. 11, pp. 65-80, 2014. (In Indonesia)

[23] Gokce, C.G.S., Aydin, S., and Arayici, S., "Comparison of Activated Carbon and Pyrolyzed Biomass for Removal of Humic Acid from Aqueous Solution", Open Environ Pollut Toxicol J, vol. 1, pp. 43-48, 2009.

[24] Thommes, M., Katsumi, K., Alexander V. Neimark, James P. O., Rodriguez-Reinoso, F., Rouquerol, J., and Kenneth, S.W.S., "Physisorption of Gases, with Special Reference to the Evaluation of Surface Area and Pore Size Distribution (IUPAC Technical Report)", Pure and Applied Chemistry, vol. 87 (9-10), pp. 1051-69, 2015. 
[25] Daud, W.M.A.W., Ali, S.S.W., and Sulaiman, M.Z., "The Effects of Carbonization Temperature on Pore Development in Palm-Shell-Based Activated Carbon", Carbon, vol. 38, pp. 1925-1932, 2000.

[26] Martinez, M.L., Agnese, M., and Guzman, C., "Making and Some Properties of Activated Carbon Produced from Agricultural Industrial Residues from Argentina”, $J$ Argent Chem Soc., vol. 91, pp. 103-108, 2003.

[27] Yu, K., Xiaoping, Z., and Shaoqi, Z., "Adsorption of Methylene Blue in Water onto Activated Carbon by Surfactant Modification", Water, vol. 12 (587), pp. 1-19, 2020.

[28] Belloa, O.S., Adeogunb, I.A., Ajaeluc, J.C., and Fehintolad, E.O., "Adsorption of Methylene Blue Onto Activated Carbon Derived from Periwinkle Shells: Kinetics And Equilibrium Studies", Chemistry and Ecology, vol. 24 (4), pp. 285-295, August 2008.

[29] Liang, S.X. Guo, Feng, N., and Tian, Q., "Isotherms, Kinetics, and Thermodynamic Studies of Adsorption of $\mathrm{Cu}^{2+}$ from aqueous solutions by $\mathrm{Mg}^{2+} / \mathrm{K}+$ Type Orange Peel Adsorbent", J. Hazard. Mater, vol. 174, pp. 756-762, 2010.

[30] Low, L.W., Teng, T.T., Ahmad, A., Morad, N., Wong, Y.S., “A Novel Pretreatment Method of Lignocellulosic Material as Adsorbent and Kinetic Study of Dye Waste Adsorption", Water Air and Soil Pollut, vol. 218, pp. 293-306, 2011.

[31] Pathania, D.S. and Sharma, P. S., "Removal of Methylene Blue by Adsorption onto Activated Carbon Developed from Ficus Carica Bast", Arab. J. Chem, vol. 10 (Suppl. 1), pp. S1445-S1451 1-7, 2017.

[32] Ho, Y.S., Malaryvizhi, R., and Sulochana, N., "Equilibrium Isotherm Studies of Methylene Blue Adsorption onto Activated Carbon Prepared from Delonix Regia Pods", J. Environ. Prot. Sci., vol. 3 (1), pp. 1-6, 2009.

[33] Jawada, A.H., Rashida, R.A., Mohd Ishaka, M.A., and Lee, D. W., "Adsorption of Methylene Blue onto Activated Carbon Developed from Biomass Waste by $\mathrm{H}_{2} \mathrm{SO}_{4}$ Activation: Kinetic, Equilibrium and Thermodynamic Studies", Desalination and Water Treatment, vol. 57, pp. 25194-25206, 2016. 